\title{
Islamic Values in Bedhaya Sri Nawa Kumala Dance of Guruh Sukarno Putra Creation
}

\author{
Dinar Ayu Astarinny1, R.M. Pramutomo*2 \\ Postgraduate Program of Indonesia Institute of the Arts Surakarta, Indonesia ${ }^{1,2}$ \\ Email: dinarayu.astarinny@gmail.com ${ }^{1}$; masmomo@hotmail.com²
}

\begin{abstract}
Bedhaya Sri Nawa Kumala dance is a composition of Bedhaya Ketawang Dance idea manifested into a brand new form by Guruh Sukarno Putra, a choreographer and dancer who is experienced in interpreting and reinterpreting. Guruh Sukarno Putra considered that dance can be manifested by exploring the existing value in a community. The value of sacredness as in Bedhaya can be manifested in various forms and shapes. Bedhaya Sri Nawa Kumala dance performance emphasizes Surakarta Traditional Female Dance Style which dance music consisting of the teachings of Sunan Kalijaga contains Islamic values. The costumes cover the head and body of the dancers, which is a manifestation of worship to God Almighty. The method used in this research was dance ethnography with Ethnochoreology approach supported by Marco De Maramis theory explaining that art performance is multilayer. Field research was conducted to obtain data from observation, data analysis, style explanation, and write a synthesis that aims to determine the style of Bedhaya Sri Nawa Kumala dance performance by Guruh Sukarno Putra which contains Islamic Values.
\end{abstract}

Keywords: Manifestation; Bedhaya Sri Nawa Kumala Dance; Guruh Sukarno Putra.

\section{A. INTRODUCTION}

Islam has values and norms in regulating every aspect of people's life including arts in form of Music, Dance, and so forth in their respective media as the era cannot be separated from pleasure and aesthetic (Intan, 2016: 134). Arts that contain a shade of Islam are created with the intention of worship and sincerity of devotion to God Almighty by accommodating the values of local cultural traditions (Nanang, 2012: 6). Bedhaya Sri Nawa Kumala dance is a Bedhaya dance created by Guruh Sukarno Putra on Festival Kesenian Kawasan Selatan (FKKS) or Southern Arts Festival in Trenggalek Regency, East Java, on October 21, 2017. Bedhaya Sri Nawa Kumala dance is a creation of Indonesian artist who has been dabbling in dance creation. He tried to express what he has been experienced into Bedhaya dance. By the time, there will be changes in order to adapt to new circumstances along with the society growth (Soeryono Soekanto, 1990:345).

Guruh Sukarno Putra created the dance because he was inspired by Bedhaya Ketawang dance that is closely related to the Southern Sea (Indian Ocean), starting from the gesture, the floor pattern, the number of dancers to the music style. Although it is not as complete and as grand as Bedhaya Ketawang dance that was created through complicated stages and calculations and was only presented for the upper middle class, Bedhaya Sri Nawa Kumala dance is able to present a sacred performance and make the audience live up to the atmosphere. Supported by its dance music and performance location which is on the shoreline, consequently, the audience would feel a sensation that is different from other performances.

Bedhaya Sri Nawa Kumala dance by Guruh Sukarno Putra was exclusively created for Trenggalek Regency, East Java. It combines Surakarta Traditional Female Dance Style and new patterns following Javanese songs. Bedhaya Sri Dance means nine shining gems. It is contained in the song that explains nine teachings of Sunan Kalijaga in living a worldly life. In the last section, Sholawat Badar (prayer) with the

\footnotetext{
* Corresponding author

Received: March 01, 2020; Revised: March 28, 2020; Accepted: March 30, 2020
} 
harmony of gamelan (Javanese traditional ensemble music) and rebana (tambourine used in Islamic devotional music) is played to accompany the dancers leaving the show.

Each pattern of Bedhaya Sri Nawa Kumala dance gestures attempts to illustrate the smoothness and harmony of gestures inspired by Bedhaya Ketawang dance. Generally, it takes the aesthetic of a Javanese Dance in Surakarta Dance Style that is presented in a popular way and becomes a new style for art enthusiasts. Bedhaya Sri Nawa Kumala dance performance serves as an entertainment that contains religious values in its Islamic music and costume style mixed with the belief in the Queen of the Southern Sea retained by the locals. Although it is full of Islamic nuance, it cannot be denied that the locals are still believing in myth and mystique that has existed since ancient times.

Description of Codrington concept used by Marett in Sejarah Teori Antropologi I (History of Anthropology Theory I) stated that "...the beginning of belief in God is an "emotion" or "thrill" resulted by human admiration for certain extraordinary things and phenomena." (Koentjaraningrat, 1980: 61).

Javanese people still believe in the existence of the Queen of the Southern Sea, Kanjeng Ratu Kidul, who rules the coastal areas of Indian Ocean. Some interviewees stated that Kanjeng Ratu Kidul is the wife of Panembahan Senopati who has a loyal maid named Nyi Rara Kidul. Nyi Rara Kidul really likes green clothes. Therefore, people believe that they should avoid wearing green clothes in the Southern coastal areas.

The relationship between art and religion can be felt by human senses because religious elements consist of ceremony, feeling, belief, and human behavior. Consequently, art is often exploited by religion as an attempt to convince belief in God Almighty. Art is an expression of spiritual experience expressed through certain media and a manifestation of devotion to God Almighty. Therefore, art can be a medium and means in increasing faith because it can convey Islamic values from Ulemas (Islamic scholars) which is believed to have good Islamic teachings. Dance is a means of presenting Islamic values in a simple and entertaining manner because the content is easy to be understood. Simultaneously, it will present interesting, easy listening, and understandable performance that contains Islamic values.

Mostly the previous research in about Islamic Da'wah less using performing arts as a tool of studies. Artistic responses from dance creation for example has still unuseful for new dimensions of Islamic studies. Hariyah's writing in Record and Library Journal Volume 2 Number 2, 2016, for example, tries to study a number of Islamic studies that contain various aspects and perspectives. However, none of them used dance media as an artistic element of responses to studies (Hariyah, 2016: 162-167).

The same thing is also found from other tulian when specifically looking at Da'wah studies as another way of interpreting Islamic values as in the writings of Nanda Khairiyah in his writings on "Islamic Education Between Expectations and Reality" published in Al-Aqidah Journal Volume 2 Number 22019 (Khairiyah; 2019: 123-124). This paper views Islamic values through the dimensions of formal education. In addition, other similar writings related to Islamic values by looking at the perspective of formal education were also conducted by Fiqh Aisyatul Farokhah, Sri Kusumo hapsari, and Mugijatna about the conception of beauty in Islamic values published in Millati Journal Volume 3 Number 2 2018, (Farokhah; 2018: 189-192).

This is important for Islamic art is manifested in certain characteristics which is based on aesthetics and creativity. A Choreographer attempts to create an aesthetic work of dance as a manifestation of worship to God Almighty. After going through complicated processes, a magnificent work which is useful for everyone who observes it in a material or spiritual way based on the respective experience. If a work is known, enjoyed by many people and having Islamic teachings, the artist will be more solemn and sincere in worship. 
Although Bedhaya Sri Nawa Kumala dance is just performed once, it has profound meaning and teachings. The problems in this research are Bedhaya Sri Nawa Kumala dance performance by Guruh Sukarno Putra requires a lot of stages in training process as well as selection of gestures and components of Bedhaya Sri Nawa Kumala dance performance. The components of Bedhaya Sri Nawa Kumala dance performance were selected in detail and carefully, such as gestures selection, floor patterns selection, dancer selection, costume selection, and properties used. This research was preliminary research to determine what Islamic values contained in Bedhaya Sri Nawa Kumala dance by Guruh Sukarno Putra.

\section{B. RESEARCH METHOD}

The research question is how Bedhaya Sri Nawa Kumala dance by Guruh Sukarno Putra contains Islamic values? The researcher attempts to explain things on Bedhaya Sri Nawa Kumala dance related to belief, experience, knowledge, and values reflected in the music of Bedhaya Sri Nawa Kumala dance. Ethnochoreology approach was used in this research with dance as the subject and the data was collected from several disciplines. This research used Marco De Maramis theory that explains: text in art performance is multilayer, starting from dancer, gestures, dance music, makeup, and costume to stage setting, etc. (Marinis, 1993; 10). This research is to determine the form of Bedhaya Sri Nawa Kumala dance by Guruh Sukarno Putra.

For writing systematics, firstly, the researcher explained Bedhaya Sri Nawa Kumala dance by Guruh Sukarno Putra that was performed at 360 Prigi beach in Trenggalek Regency, East Java. The explanation starts from dancers, number, background of dancers, and position of dancers in Bedhaya Sri Nawa Kumala dance performance. Then, gestures and floor pattern in Bedhaya Sri Nawa Kumala dance performance. Next, the music containing song and stage setting of the performance.

\section{HASIL DAN ANALISIS/RESULTS AND ANALYSIS}

Everyone knows Guruh Sukarno Putra, he was famous in the era of $60-80$ s as a songwriter and founder of a Company in the field of Art Performance. He created many works of music and dance. Most of the singers who sing his songs were famous divas in Indonesia, namely Vina Panduwinata, Titi Dj, AB Tree, Krisdayanti as well as the best male singers like the Late Chrisye and popular singers like Nino Gracia who rearranges the songs of Guruh Sukarno Putra. Simple yet deeply meaningful as well as containing an understanding of love for Indonesia are the characteristics of songs written by Guruh Sukarno Putra. In creating dance, Guruh Sukarno Putra combined traditional gestures and new gestures according to his experience during learning dancing from the masters of traditional dance of the Nation (Interview, Hassim).

Guruh Sukarno Putra unquestionable capability drawn the attention of Emil Dardak (the Regent of Trenggalek), he asked Guruh Sukarno Putra to help him preparing the Festival Kesenian Kawasan Selatan (FKKS) or Southern Art Festival on 2017 in Trenggalek Regency. Through a fair and long negotiation process since the offer has been made since April, finally Guruh Soekarno Putra through Alex (his right hand), looks for dancers for his new work, Bedhaya dance, in September.

After two months of dance training, Bedhaya Sri Nawa Kumala was performed at 360 Prigi beach and watched by Guruh Sukarno Putra; the Regent of Trenggalek, Emil Dardak, and his wife, Arumi Bachsin; as well as the ranks of government and Trenggalek people in particular on 21 October. The discussion of Bedhaya Sri Nawa Kumala was based on: performance is recognized as having multiple expressive medium, if it is analyzed along other different forms for expression: words, gestures, and stage sets (Marinis, 1993; 10)" and Sal Mulgianto in Kritik Tari (Dance Criticism) who described that "the stages in analyzing performance are observing the main components of dance performance, namely: 


\section{Dancers}

Dancers in Bedhaya Sri Nawa Kumala dance consist of nine female dancers with height of $158 \mathrm{~cm}$ above with the background of good traditional dance skill in Surakarta dance style. Alex selected dancers from Indonesia Institute of Arts (ISI) Surakarta who have good dancing skills according to him. Dancer selection was conducted by trust system without any selection. Alex trusted in a Solo dancer who has long assisted the show of Kinarya Gencar Semarak Persada (GSP) Company to find nine tall dancers who are able to dance in Surakarta style as well as being synchronized. Not all dancers of Bedhaya Sri Nawa Kumala dance were Muslims, some of them were Roman Catholic, Hindu, and Christian. They are required to wear costume and memorize the dance music as well as the gestures that were instructed by the Choreographer. The dancers performed and followed the Choreographer directions well.

As in Bedhaya Ketawang dance, each dancer has a position or name: Batak, Endhel, Apit Ngajeng, Apit Wingking, Gulu, Endhel Ajeg, Dhada, Apit Meneng, and Buncit. Dancers in Bedhaya Sri Nawa Kumala dance are not as complete as those in Bedhaya Ketawang dance. Bedhaya Sri Nawa Kumala only consists of two positions, namely Batak and Buncit. Batak dancers are always positioned in the middle and front, while Buncit dancers are at the back and corner. This distribution of task is used to facilitate the move according to the floor pattern. Bedhaya Sri Nawa Kumala dancers should understand the techniques of classical Javanese dance according to the applicable standard rules, namely Hastha Sawanda or the eight rules including pacak, pancat, ulat, lulut, luwes, wilet, irama, and gendhing. The rules will result in a good Javanese dance in Surakarta dance style, although the performance of past and present Bedhaya dancers has changed over a long period of time.

\section{Gesture}

Gestures in Bedhaya Sri Nawa Kumala dance was composed by Guruh Sukarno Putra by considering choreography elements including space, time, and dynamics. Bedhaya dance style is rearranged similar to Bedhaya Sri Nawa Kumala dance which still holds Bedhaya structure consisting of three parts: Forward beksan, beksan, kapang-kapang backward accompanied by different music to create atmosphere in every part of dance in form of regu, wingit, and others.

\section{Maju beksan}

The dancers come from right side of the back corner of the stage one by one to create a straight line with steps called kapang-kapang. Kapang-kapang in Javanese means walking slowly with the foot sole take a step in front of the other alternately, the front leg forms a snake path. The first dancer who comes out is Buncit followed by the others. Batak are in the middle. After all dancers are in a straight line, they face left slowly to the audience. Then, they walk forward forming floor pattern of letter "V" with a Batak dancer positioned in the middle front.

\section{Beksan}

Beksan in Javanese means a dance form, beksan in this case is the complete performance of Bedhaya Sri Nawa Kumala dance content starting from Sembahan which means honor to all, it is in a sitting position like last tahiyat in Prayer, hands are positioned in the middle of the thighs, followed by greetings to right and left, head face to right and left followed by hand rub on the face and finished by greetings, accompanied by song of salam in Islam. Then, kneeling on one foot (jengkeng sembahan) again like the vocabulary gesture of female tradition followed by standing up and starting from vocabulary one to nine with srisig vocabulary movement namely small run with fast tempo as well as floor pattern movement. The vocabulary used are Hoyogan, sekaran separo, enjer, lincak gagak, rancak menjangan, sekar suwun, glebak an, ukel manis kengser, leyek an, and kebaran by Guruh Soekarno Putra. The last part of Beksan is nikelwarti which is sembahan at the end of the dance. 


\section{Kapang-kapang mundur}

Kapang-kapang mundur is walking backwards leaving the stage by moving right foot forward debeg gejug left foot forward debeg gejug right foot lined with left foot hoyog left foot ogek bounce while opening fan push to the right gedheg shake head performed 3 times. Then, it was followed by walking to the left and three dancers each leave the stage to the right accompanied by Sholawat Badar dance and use orange fan as the property which is contrast to the green costume.

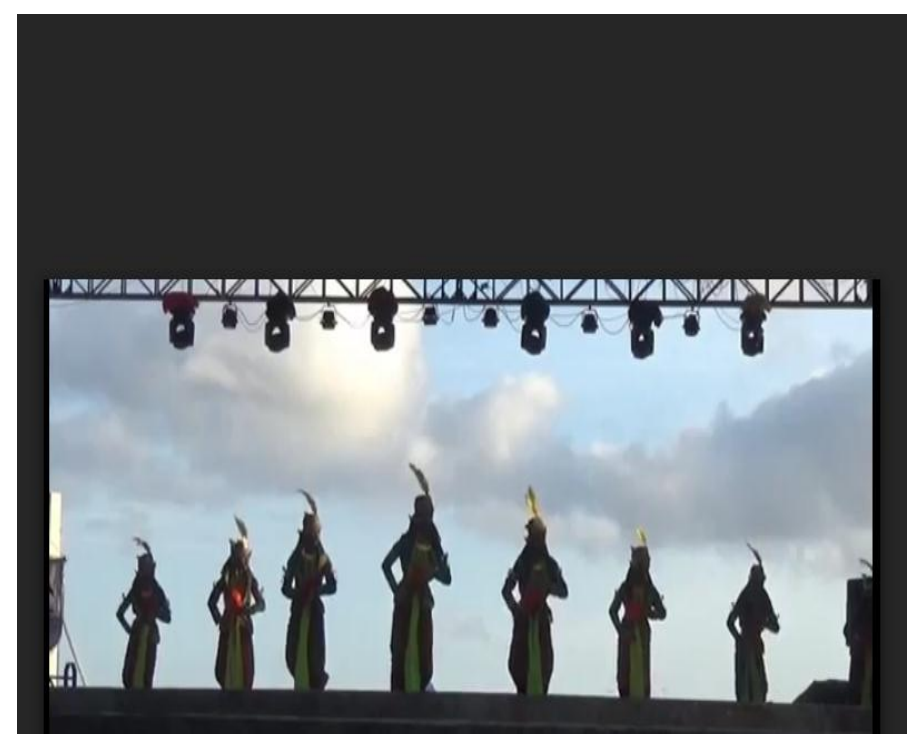

Figure 1 Floor pattern position of the letter "V" on Bedhaya Sri Nawa Kumala dance performance. (Picture by Wahyu, 2017)

Floor pattern is the position of dancers in filling spaces on the stage of Bedhaya which is called Rakit. Floor pattern used in Bedhaya Sri Nawa Kumala dance consists of seven floor patterns composed by Guruh Soekarno Putra. They are the letter V, circle, wind direction, rakit three on three, straight rakit three on three, diagonal, and jejer wayang as shown in figure 1 . The letter $V$ position is the dancers stand in line forming the letter $\mathrm{V}$ with the position of batak in the middle front. Circle, the dancers form a circle. Then, the position of wind direction is the eight dancers facing each eight wind direction: East, Southeast, South, Southwest, West, Northwest, North, and Northeast. The Batak is the center of wind. Rakit three on three is the nine dancers are divided into groups of three dancers, forming small circle, then each group lined up into position of three on three straight to sideway and backward. Then diagonal, the nine dancers split the stage in diagonal position from the right front end corner to the left back corner. Next, srisig form a straight jejer wayang like puppet (wayang) arrangement.

\section{Music or Karawitan (Traditional Javanese Music)}

Bedhaya Sri Nawa Kumala dance performance is accompanied by several music Instruments, namely Sounds of Nature, Karawitan Slendro and Pelog, and Rebana which are divided into three parts:

Maju beksan is accompanied by sounds of nature such as sound of waves and wind that bring up sacred atmosphere. During the rehearsal, the atmosphere was so sacred even some of the audience get goosebumps, but it is less sacred at the time of the show because the number of audiences and street vendors at Prigi beach who offer merchandises using music.

Beksan is accompanied by musical recording of karawitan dance music with a duration of 7.35' (seven minutes thirty-five second). The musicians are selected from Wayang Barata Jakarta. Guruh 
Soekarno Putra created and wrote the music himself and then submitted it to the musicians. The musicians need a week to learn and play the music. Once the musicians are ready, they record the song to be used for practicing and performing. The song used is Javanese song containing nine teachings of Sunan Kalijaga.

4. Song of Bedhaya Sri Nawa Kumala
Assalamu alaikum warahmatullah hibarakatuh
Amarsudi sinden gendhing bedaya
Bedaya Sri Nawa Kumala
Ginelar ing Trenggalek Kabupaten Kabupaten Surya kaping dwi eka wulan dasa wulan dasa Warsa masehi dwi suwung eka sapta Hinggih
menika wewerah pitutur sabda kang suhud minulya kanjeng Sunan Kalijaga
Ande kaping eka urip iku urup babo babo urip iku urup
Ande kaping dwi memayu mayu hayuning bawana hayuning bawana
Ande kaping tri suradiraja jayadiningrat jayadiningrat Lebur dening dening pangastuti Pangastuti dening pangastuti
Ande kaping catur nglurug tanpa bala menang tanpa tanpa ngasorake Sekti tanpa aji tanpa aji sugih tanpa tanpa banda Ande kaping panca datan serik lamun lamun ketaman lamun ketaman Datan susah datan susah lamun lamun kelangan lamun kelangan
Ande kaping sat aja gumunan aja getunan aja getunan aja kagetan aja aleman aja aleman
Ande kaping sapta aja ketungkul aja ketungkul marang kalungguhan marang kalungguhan Kadonyan lan kemareman lan kemareman lan kemareman
Ande kaping hasto aja keminter mundhak keblinger mundhak keblinger Aja cidra aja cidra mundhak cilaka mundhak cilaka
Ande kaping nawa aja adigang adigung lan adiguna lan adiguna

\section{Translation of Bedhaya Song:}

Nine diamonds of nobility

Assalamualaikum warahmatullahi wabarakatuh, teachings of sinden gending bedaya, Bedaya Sri Nawa Kumala, is conducted in Trenggalek Regency in the 21st of the tenth month, the tenth month of AD 2017. It is the teachings of the noble guardian, Kangjeng Sunan Kalijaga; the first, life is a flame yes life is a flame; the second, beautifying the beauty of the world; the third, every hatred and anger will be decreased by tenderness, wisdom, and patience; the fourth, attacking without troops, winning without undermining, being Holy without knowledge/heirlooms, being rich without health; the fifth, not hurt when disaster strikes, not grieve when lost; the sixth, don't be astonished easily, don't regret easily, don't be surprised easily, don't be spoiled; the seventh, don't be lulled by position, worldliness and contentment, and satisfaction; the eight, don't think that you're the most intelligent person to stay in the right path, don't do bad thing cause it may harm you; the nine, don't boast your strength, power, and intelligence.

From the explanation above, it can be seen that the song in Bedhaya Sri Nawa Kumala contains Islamic values taught by Sunan Kalijaga for a betterment in the world. Sunan Kalijaga is one of Nine Guardians (Wali Sanga), the propagator of Islam in Java. According to the myths, Sunan Kalijaga was able to make the Queen of Southern Sea embrace Islam by using Vests with Holy verses of Qur'an printed on it.

The third part is mundur beksan accompanied by music in the form of Sholawat Badar and Gamelan and rebana instrumental music with the sequence of swaps:
a) Gamelan
$1 \mathrm{x}$
b) Vocal
$2 \mathrm{x}$
c) Gamelan
$1 \mathrm{x}$ 
$\begin{array}{lll}\text { d) Vocal } & 2 x & \\ \text { e) Gamelan } & 1 x & \\ \text { f) Rebana } & 2 x & \\ \text { g) Gamelan } & 2 x & \text { stop }\end{array}$

The Vocal is filled with Sholawat Badar with the text as follows:

Shalawat Badar Text

Sholaatullah salaamullah 'alla thooha rasuulillah

Sholaatullah salaamullah 'alla yassin habiibillah

Tawassalna bi bismillah Wabil haaadi rosulillaah

Wakulli mujahidin lillah Bi ahlii badri yaa Allah

Illaahi sallimi ummah minal aafaati wannigmah

Wa min hammin wa min ghummah bi ahlil badri yaa Allah

Ilaahi-ghfir wa akrimna binaili mathoolibin minna

Wadafi masaa-ati anna bi-ahlil badri ya Allah

Wa sholli'alammabil barri billa 'addi wa laa hasri

Wa ali sadatin ghurri bi ahlil badri yaa Allah

\section{Outfit and Makeup}

Outfit and makeup are crucial elements in a show to strengthen the atmosphere and bring up the characters in Bedhaya Sri Nawa Kumala dance. The nine dancers wear the same outfit and makeup as shown in figure 2. For makeup, the dancers use blue, black, and red eye shadow, and white colored highlight. Their eyebrows are dark brown, orange blush on for cheek, and bright red lipstick. The makeup is not too flashy to show the dancers' natural beauty because the show is performed during the day. The color selection was on the deal of the dancers.

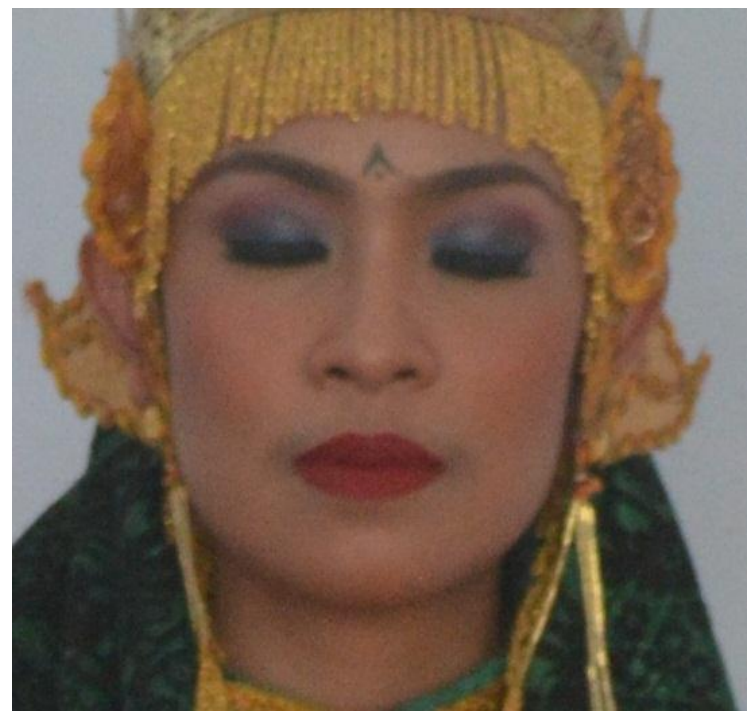

Figure 2 Makeup of Bedhaya Sri Nawa Kumala dancers (Wahyu, 2017)

Head decorations are green triangular hijab to cover the hair, jamang (crown) and sumping (winglike shape jewelry) on the ears. The top is green velvet that matches the hijab color. The sleeves are long and the collar is straight up to the neck in order to cover the neck. Both shoulders are decorated with klat (ancient jewelry on shoulders). The waist is wrapped by a gold belt and a light green shawl. The bottom is Jarik samparang (traditional Javanese skirt) which is folded and filled with pieces of gold paper that give 
effect when it is wagged. The color green was selected by Guruh Sukarno Putra because it is the favorite color of the Queen of the Southern Sea. The costume was designed by Guruh Sukarno Putra as shown in figure 3 .

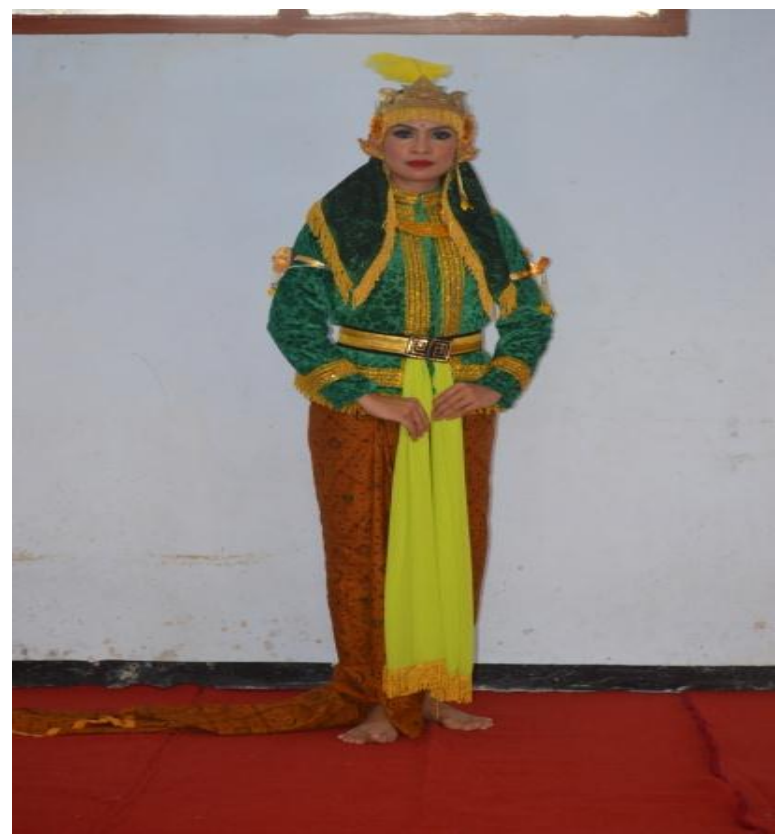

Figure 3 Front look of Bedhaya Sri Nawa Kumala outfit and makeup of the dancer (Wahyu, 2017)

\section{Show Setting}

Bedhaya Sri Nawa Kumala dance was performed at 360Prigi beach, one of the southern coastal area on the edge of Indian Ocean that becomes the center and the largest port in the South of Java. A proscenium-like stage was built at Prigi beach, so the audience only watch from one direction, i.e. from the front. Bedhaya Sri Nawa Kumala dance was performed in the beach with the southern sea as the background. The roof of the stage was covered by tarpaulin so the audience view was not distracted upwards. Distance from the front row audience to the stage was about 10 meters. The front seats were occupied by invited guests or VIP guests. While the general audiences were standing at the side of the stage with a height of 1.5 meters. The entrance to the show was on the right and left sides.

\section{CONCLUSION}

Guruh Sukarno Putra is an Indonesian Artist who composes various Indonesian music and dance creation by applying combinations of traditional and dance creation of Indonesia. The works of Guruh Soekarno Putra are well known by Indonesian society in the 70s era. In 2017, Guruh Sukarno Putra created Bedhaya dance which is closely related to Islamic elements in Bedhaya Sri Nawa Kumala dance that was performed at Festival Kesenian Kawasan Selatan (Shouthern Art Festival) of Trenggalek Regency, East Java. Guruh Sukarno Putra has a background of art from his experience in learning traditional dance up to dance creation. Artists like Guruh Sukarno Putra attempt to create innovation based on their experience to respond to today's phenomena. Bedhaya Sri Nawa Kumala dance combines old patterns into a new creation, such as kapang-kapang in maju beksan, leyekan in beksan, sekar suwun, srisig, and kapang-kapang mundur in mundur beksan. The number of dancers was nine dancers with two positions: Batak and Buncit, and floor pattern filling the stage spaces. The combination of Islamic values can be seen from the costume 
design that covers the hair and body of the dancers from the neck to the wrists and legs. The song also contains nine teachings of Sunan Kalijaga, and Sholawat Badar.

Music, gestures, and costumes are the works of Guruh Sukarno Putra assisted by the team of Kinarya Gencar Semarak Persada (GSP) Company. In addition to the order of Trenggalek Regency Government, Bedhaya Sri Nawa Kumala dance by Guruh Sukarno Putra also tried to express the spiritual experience in a show as the manifestation of worship to God Almighty. Islamic values were not just included in Bedhaya Sri Nawa Kumala dance, it also required consideration and sophisticated combination in the presentation. According to Guruh Sukarno Putra, Sunan Kalijaga teachings in the song of Bedhaya dance is closely related to the illustration of. Some historical sources stated that Sunan Kalijaga was able to make the Queen of the Southern Sea embraces Islam.

\section{REFERENCES}

Adshead Janed, Hodgens, Pauline, Briginshaw, Valery A, Huxley, Michael. Dance Analysis (edited by Janed Adshead). London: Cecilcourt.1988.

Agus Tasman, Analisa Gerak dan Karakter. Surakarta: ISI Press. 2008

Ahimsa-Putra, Heddy Shri. Ketika Orang Jawa Nyeni. Yogyakarta: Galang Press dan Yayasan Adhi Karya untuk Pusat Penelitian Kebudayaan dan Perubahan Sosial Universitas Gadjah Mada, 2000.

Dinar, Ayu. "Koreografi Indonesia Jaya di Group Tari Kinarya Soerya Soemirat Pura Mangkunegaran", Skripsi, Institut Seni Indonesia, Surakarta, 2014.

Farokhah. Fiqih Aisyatul, Sri Kusumo Habsari, Mugijatna. "The Curse of Beauty: Sexuality Exploitation towards Sales Promotion Girls' Body Viewed from the Islamic Perspective", Millatī, Journal of Islamic Studies and Humanities Vol. 3, No. 2, Des. 2018

Hariyah. "Research Trends in Islamic Studies on Journal of Research and Development and Training Center Ministry of Religious Affairs: Using Co-Words", RECORD AND LIBRARY JOURNAL Volume 2, Nomor 2, Juli-Desember 2016

Hawkins, Alma M, Creating Through Dance: Mencipta Lewat Tari.Terj. Y. Sumandiyo Hadi. Yogyakarta: ISI Yogyakarta. 1990

Khairiyah. Nanda, "Pendidikan Islam Antara Harapan dan Realita" Jurnal Al-Aqidah STIA Salatiga, VOLUME 2 NO. 2 TAHUN 2019

Maramis, Marco De. The Semiotics of Performance. USA: Indiana University Press. 1993

Murgianto, Sal, Kritik Tari. Jakarta: MSPI. 2002.

Pengkajian Seni. "Manajemen Seni", Tugas Kuliah, Pasca Sarjana Institut Seni Surakarta, 2015.

Pramutomo, RM. Antropologi Tari. Surakarta: STSI Press. 2005

Quraatul Aini, Intan. "Nilai-nilai Pendidikan Islam yang Terkandung dalam Tari Rateb Meuseukat". Didaktika, Jurnal Ilmiah Vol. 17 No. 1 (Agustus 2016).

Rizali, Nanang. "Kedudukan Seni dalam Islam". Tsaqafa, Jurnal Kajian Seni Budaya Islam Vol. 1 No. 1 (Juni 2012)

Robert Leuer. Perspekti Tentang Perubahan Sosial.Terj. Santika Yogyakarta: Kreasi Wacana. 1993. Slamet, Md, Melihat Tari. Surakarta: Citra Salin. 2016.

Soekanto, Soeryono. Sosiologi Suatu Pengantar (edisi ke-empat). Jakarta: Raja Grafindo Persada. 1990.

\section{Webtography}

http://.blogkinaryagspcompany.com 25 November 2013

http://kinaryasoeryasoemirat.com 14 November 2013

http://wikipedia.com

\section{Interviews}

Allexander Hassim (54) Jakarta, Choreographer of Kinarya Gencar Semarak Persada (GSP) Company. 
Dudit Gunawan (43) Jakarta, Choreographer

Girinanda Chrisma Putri (26) Surakarta, Dancer of Bedhaya Sri Nawa Kumala Guruh Sukarno Putra (63) Jakarta, Indonesian Artist 